\title{
Urethral Squamous Cell Papilloma: A Rare Case Report and Review of the Literature
}

\section{Üretranın Skuamöz Hücreli Papillomu: Nadir Bir Olgu Sunumu ve Literatürün Gözden Geçirilmesi}

\author{
(D) Serdar Çelik1 , (D) Halil Hakan Özgür², (D) Kutsal Yörükoğlu33, (D) Mehmet Uğur Mungan4 \\ 1 Tunceli State Hospital, Clinic of Urology, Tunceli, Turkiye \\ 2 Private Güneş Medical Pathology Laboratory, İzmir, Turkiye \\ ${ }^{3}$ Dokuz Eylül University Faculty of Medicine, Department of Pathology, İzmir, Turkiye \\ ${ }^{4}$ Dokuz Eylül University Faculty of Medicine, Department of Urology, İzmir, Turkiye
}

\begin{abstract}
Urethral squamous cell papilloma is a benign lesion commonly presenting with lower urinary tract symptoms, such as dysuria and intermittent poor urinary flow. Surgical excision and careful pathological investigation are required for definite diagnosis and treatment. The probability of recurrence is fairly low. These lesions are generally observed in the urethra in post-menopausal women. This paper presents a case of squamous cell papilloma in the male anterior urethra in an 18-year-old male patient, who underwent surgical excision, and a literature review.
\end{abstract}

Keywords: Papilloma, Tumor, Urethra

$\ddot{0 z}$

Üretranın skuamöz hücreli papillomu genellikle dizüri ve aralıklı idrar akış hızında azalma gibi alt üriner sistem semptomları ile bulgu veren benign lezyonlardır. Kesin tanı ve tedavi için cerrahi eksizyon ve dikkatli bir patolojik inceleme gerekmektedir. Nüks riski oldukça düşüktür. Bu lezyonlar genellikle menopoz sonrası kadınların üretrasında gözlenmektedir. Fakat, bu yazıda literatür eşliğinde erkek anterior üretrası kaynaklı skuamöz hücreli papillomu olan ve cerrahi eksizyon yapılan 18 yaşında erkek hasta sunulmaktadır.

Anahtar Kelimeler: Papilloma, Tümör, Üretra

\section{Introduction}

Squamous cell papilloma is a benign epithelial tumor rarely observed in the distal urethra in both sexes (1). The majority of lesions are seen in women in the external meatus. Urethral caruncle, urethral prolapse, urethral diverticulum and periurethral gland abscess are included in the differential diagnosis (2). Generally, these lesions are observed in hypoestrogenic state in postmenopausal women and are reported to develop from urethral caruncle background (3). Careful histological investigation is important for diagnosis (2). The clinical importance of these non-invasive lesions is unknown, though some case reports are available in the literature.
In this paper, we aimed to present an 18-year-old male patient with the diagnosis of squamous cell papilloma in the distal urethra and a literature review.

\section{Case Presentation}

An 18-year-old male patient admitted to our clinic with the complaints of intermittent dysuria and occasional reduction in urine flow rate in recent times. Physical examination revealed a polypoid lesion protruding from the external meatus (Figure 1). There was no other pathology identified in the external genital area. Due to the possibility of multifocality, urethrocystoscopy was planned. Urethrocystoscopy showed a solitary polypoid lesion in the distal fossa navicularis, protruding from the external

Correspondence: Serdar Çelik MD, Tunceli State Hospital, Clinic of Urology, Tunceli, Turkiye

Phone: +90 2324123451 E-mail: serdarcelik84@hotmail.com ORCID-ID: orcid.org/0000-0003-0939-9989

Received: 15.03.2017 Accepted: 27.04.2017

Cite this article as: Çelik S, Özgür HH, Yörükoğlu K, Mungan MU. Urethral Squamous Cell Papilloma: A Rare Case Report and Review of the Literature. J Urol Surg 2015;5(2):123-125.

๑Copyright 2018 by the Association of Urological Surgery / Journal of Urological Surgery published by Galenos Publishing House. 
meatus. Urethroscopy of the anterior and posterior urethra appeared to be normal, and cystoscopy revealed no additional pathology in the bladder. Surgical excision was performed for the polypoid lesion. Histologically, it was composed of papillary cores with overlying benign squamous epithelium (Figure 2). Immunohistochemical staining was negative for human papillomavirus (HPV) and p16, thus, pathological diagnosis of squamous cell papilloma was made.

In the postoperative $12^{\text {th }}$ month after surgical excision, the patient had no complaints and was monitored by our clinic with no recurrence.

This study is retrospective designed study.

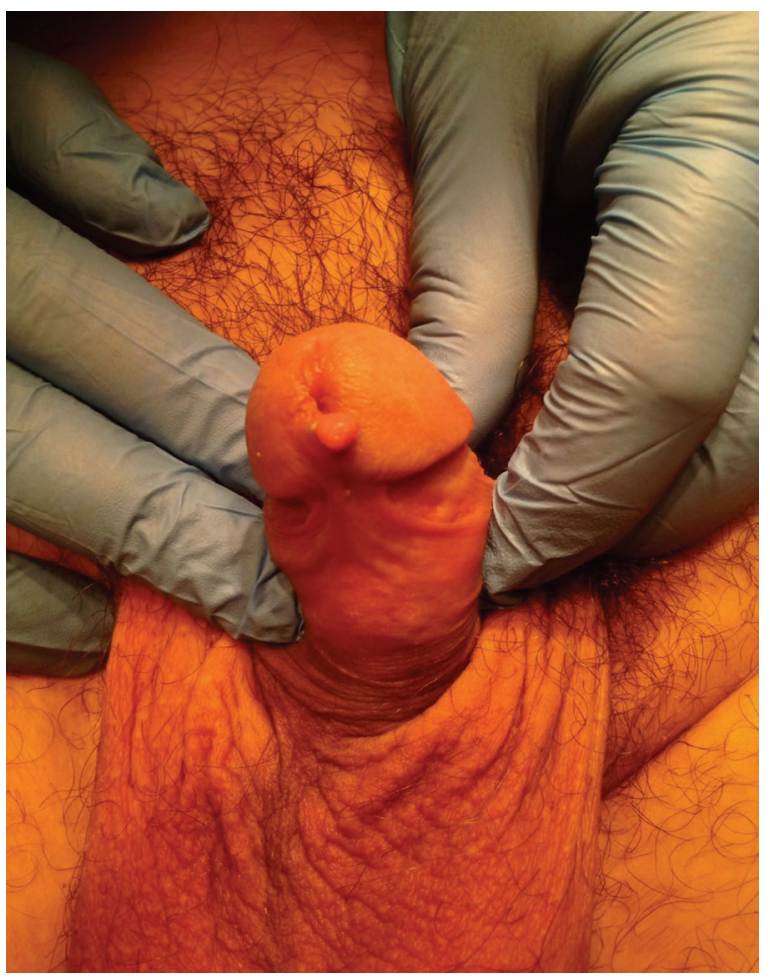

Figure 1. Appearance of squamous cell papilloma sourced in the anterior urethra, protruding from external meatus before surgical excision

\section{Discussion}

Squamous cell papilloma is a rarely observed benign lesion presenting with irritative urinary symptoms, generally identified in women over the age of 40 years (4). The patient may have symptoms, such as dysuria, intermittent hematuria, difficulty in voiding, low urinary flow rate and residual urine sensation after voiding (4). In women, lesions are generally observed in the distal urethra protruding from the external meatus (4). Evaluation with cystoscopy is an appropriate approach. Urethral caruncle, condyloma accuminatum, urethral prolapse, urethral diverticulum and periurethral gland abscess are important pathologies in the differential diagnosis (2). There is no information related to male cases in the literature, however, for differential diagnosis, anterior urethral pathologies are important. When anterior urethral pathologies are examined, congenital urethral polyp in the anterior urethra, fossa navicularis pathologies (stenosis, Guerin's sinus), anterior urethral valve, syringocele (dilatation of Cowper's gland ducts), congenital bulbous urethral stricture, condyloma accuminatum, and especially botryoid sarcoma polyps should be taken into the consideration in the differential diagnosis $(5,6,7,8)$. Definite diagnosis of squamous cell papilloma is made by careful pathological investigation. In a study investigating the correlation of squamous cell papilloma with HPV evaluated verrucous carcinoma, condyloma acuminata and urethral squamous cell papilloma cases, no correlation was observed (8). As a result, to exclude HPV and p16 immunostaining, clear definition of squamous cell papilloma is important. Microscopic investigation of the lesion demonstrates koilocytotic alterations and wrinkled hyperchromatic nuclei of squamous cells $(8,9,10)$. In our patient with a polypoid lesion in the distal fossa navicularis and protruding from the external meatus, urethrocystoscopy was performed to aid differential diagnosis and to research the presence of additional pathologies. When additional pathologies were not identified, surgical excision was performed. Pathological investigation was negative for HPV and p16 in accordance with the literature and the diagnosis of squamous cell papilloma was made. Recurrence after surgery in urethral squamous cell papilloma is rare,
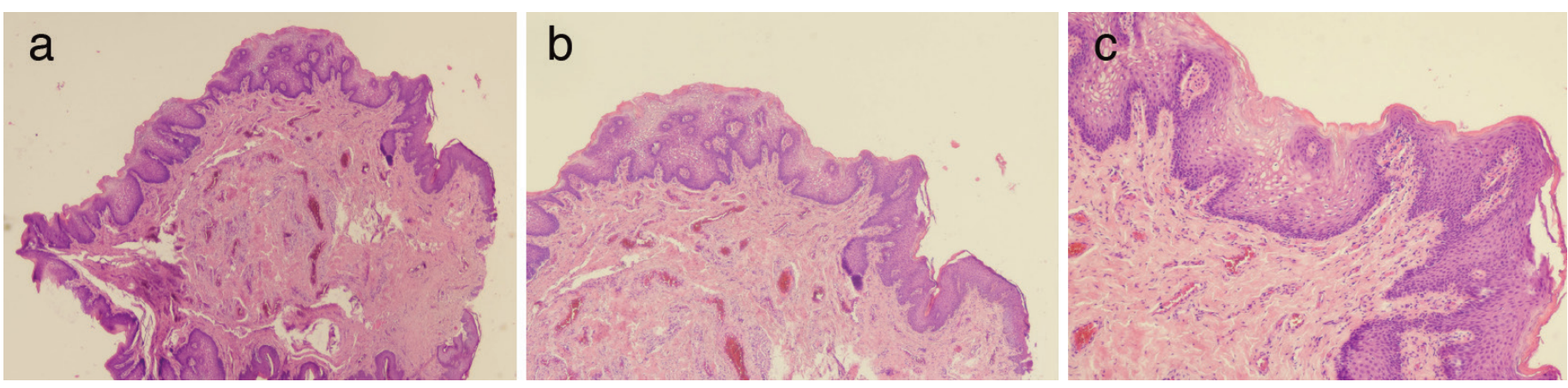

Figure 2. Classical squamous papilloma with a stalk devoid of inflammatory infiltration, without koilocytotic and nuclear atypia and keratinization (hematoxylin \& eosin, $a: 4 x, b: 10 x, c: 20 x)$ 
however, as there is a limited number of case reports in the literature, definite information cannot be given (8). The largest series in the literature comprises 5 patients. Two of these 5 cases could not be monitored so they were not assessed. Two patients did not have recurrence during follow-up and one patient was reported to have a lesion accompanied by low-degree urothelial carcinoma (11). However, when squamous cell papilloma cases are examined, the majority of patients appear to have a low risk for both urothelial carcinoma and HPV infection (4). There is no clear follow-up plan after surgical excision in the English literature; as a result, it is recommended that a follow-up plan can be determined based on physical examination and presence of symptoms (4). As recommended, we monitored our patient with physical examination and questioning of symptoms; and no recurrence was detected in the postoperative $12^{\text {th }}$ month. In conclusion, urethral squamous cell papilloma is usually a benign lesion, generally occurring in the urethra in women above the age of 40 years and presenting with irritative urinary symptoms. Diagnosis can be made by urethrocystoscopy which is the accepted treatment with surgical excision. The probability of recurrence is usually low. In some cases, these lesions may be found in the female middle urethra and the male anterior urethra; other important anterior urethral pathologies and botryoid rhabdomyosarcoma polyps must be kept in mind for differential diagnosis.

\section{Ethics}

Informed Consent: Retrospective study.

Peer-review: Externally peer-reviewed.

\section{Authorship Contributions}

Surgical and Medical Practices: H.H.Ö., K.Y., M.U.M., Concept: S.Ç., Design: S.Ç., Data Collection or Processing: S.Ç., Analysis or
Interpretation: S.Ç., H.H.Ö., K.Y., M.U.M., Literature Search: S.Ç., Writing: S.Ç.

Conflict of Interest: No conflict of interest was declared by the authors.

Financial Disclosure: The authors declared that this study received no financial support.

\section{References}

1. Melicow MM, Roberts TW. Pathology and natural history of urethral tumors in males: Review of 142 cases. Urology 1978;11:83-89.

2. Wein AJ, Kavoussi LR, Novick AC, Partin AW, Peters CA. Campbell-Walsh Urology, 10th ed. Philadelphia, Elselvier, 2012, pp 2272-2289.

3. Conces MR, Williamson SR, Montironi $R$, Lopez-Beltran A, Scarpelli M, Cheng L. Urethral caruncle: Clinicopathologic features of 41 cases. Hum Pathol 2012:43:1400-1404.

4. Gustafson P, Fenster HN, So Al. Urethral squamous cell papilloma: Case report and literature review. Can Urol Assoc J 2014;8:364-365.

5. Anandan N, Shetty S, Patil K, Ibrahim Al. Acute urinary retention caused by anterior urethral polyp. Br J Urol 1992;69:321-322.

6. Kajbafzadeh AM, Elmi A, Payabvash S, Sina A, Arshadi H, Sadeghi Z. The urethral valve of Guérin and lacuna magna: clinical presentations and urodynamic findings. Pediatr Surg Int 2007;23:873-878.

7. Adorisio O, Bassani F, Silveri M. Cobb's collar: a rare cause of urinary retention. BMJ Case Rep 2013:2013.

8. Lopez-Beltran A, Requena MJ, Alvarez-Kindelan J, Quintero A, Blanca A Montironi R. Squamous differentiation in primary urothelial carcinoma of the urinary tract as seen by MAC387 immunohistochemistry. J Clin Pathol 2007;60:332-335

9. Cheng L, Leibovich BC, Cheville JC, Ramnani DM, Sebo TJ, Nehra A, Malek RS, Zincke $H$, Bostwick DG. Squamous papilloma of the urinary tract is unrelated to condyloma acuminata. Cancer 2000;88:1679-1686.

10. Bostwick D, Cheng L. Urologic surgical pathology. 2nd ed. Philadelphia, PA. Elselvier, 2008.

11. Guo CC, Fine SW, Epstein JI. Noninvasive squamous lesions in the urinary bladder: A clinicopathologic analysis of 29 cases. Am J Surg Pathol 2006;30:883-891. 